NRPB and knows that the Board is an advisory body. It could never have "directed that the dose limit for workers be immediately reduced from 5 rems per year to 1.5 rems per year" (p. 247). Indeed, it did not even recommend such a reduction. It did suggest that, while the limits remain at their present level, it would be prudent to adopt some time-averaged restriction so as to achieve an average effective dose equivalent of $15 \mathrm{mSv}$ per year.

This is a good book, one that deserves a wide audience. It does not tell the whole story, nor is it without bias. But then, books without bias make dull reading, which is not a charge that can be levelled at Catherine Caufield.

John Dunster, 52 Thames Street, St Ebbes, Oxford OX1 1SU, UK, was formerly Director of the National Radiological Protection Board.

\section{In the country}

\section{John S. Perry}

The Weather Journals of a Rutland Squire: Thomas Barker of Lyndon Hall (1722-1809). Edited by John Kington. Rutland Record Society, Rutland County Museum, Catmos Street, Cakham LE15 6HW, UK: 1989. Pp.217. Pbk 116.50.

In the journals of the Squire of Lyndon Hall, 1751 was a year "all on the extreams". His bees had been "so weaken'd by the cold and wet mid May which hindered their working for their numerous young ones, that without feeding them . several would have dyed". Oats were 12 shillings a quarter in the British Midlands "country" of Rutland. In other countries, the French vintage was bad; earthquakes troubled Finland; droughts beset Italy and Carolina. But in Rutland, 2.656 inches of rain were to be found in the Squire's cistern gauge, situated $7 \mathrm{ft} 3$ inches above the ground.

Employing no doubt the same scrupulously legible round hand of even the earliest of his journals, the Squire in later years communicated to the Royal Society's Philosophical Transactions not only the weather of Lyndon Hall, but also his calculations of comets' orbits and astronomical inferences from Eratosthenes and Ptolemy. To other audiences he presented his theological views on the benefits of baptism.

Thomas Barker, grandson of William Wiston, Newton's protégé and successor at Cambridge, emerges from the pages of this lovingly composed volume as a complex and vital man of his time, wedded to the soil of his comfortably selfcontained "country" of Rutland, but intellectually linked with the larger worlds of politics, religion, science and, above all, nature. His life spanned the most eventful years of the eighteenth century, but little of that turbulence intrudes into the voluminous journals that he began as a teenager. His lifelong passion was the ever-changing weather, together with its effects on his agrarian world. Thus, his meteorological journals contain not only notes of the conventional variables of pressure, temperature, wind and precipitation, but also detailed accounts of storms, droughts, floods, crop yields, pests - a rich, moving panorama of his century that has provided a treasure trove for students of past climate.

John Kington, a climatologist at the

from its members. But few of these records acquired the quality, continuity and wide dissemination of Barker's, which from 1771 were annually published in the Philosophical Transactions. Barker's reputation spread far beyond Rutland, for he was invited to contribute to an account of the severe winter of 1789-1790 being compiled by the Académie des Sciences of the unfortunate Louis XVI.

As Kington's account amply demonstrates, Thomas Barker was a pioneer in appreciating the importance of wellcontrolled, quantitative, continuous and extended observations in the study of nature. His journals show a keen awareness of the regularities of the British climate, and of the longer-term climatic fluctuations of his time. As a meteorologist of sorts, I stand in awe of Barker's insight and industry. But what sort of man was he? Some hints emerge from Kington's scholarship. A friend thought that marriage might relieve his "extreme Abstractedness \& Speculativeness". At 61 , he had a "streight belly", undertook a journey of 118 miles on horseback "without the least complaint or fatigue" 234 and ran foot races with his

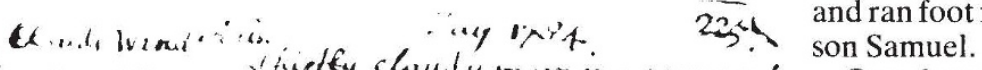

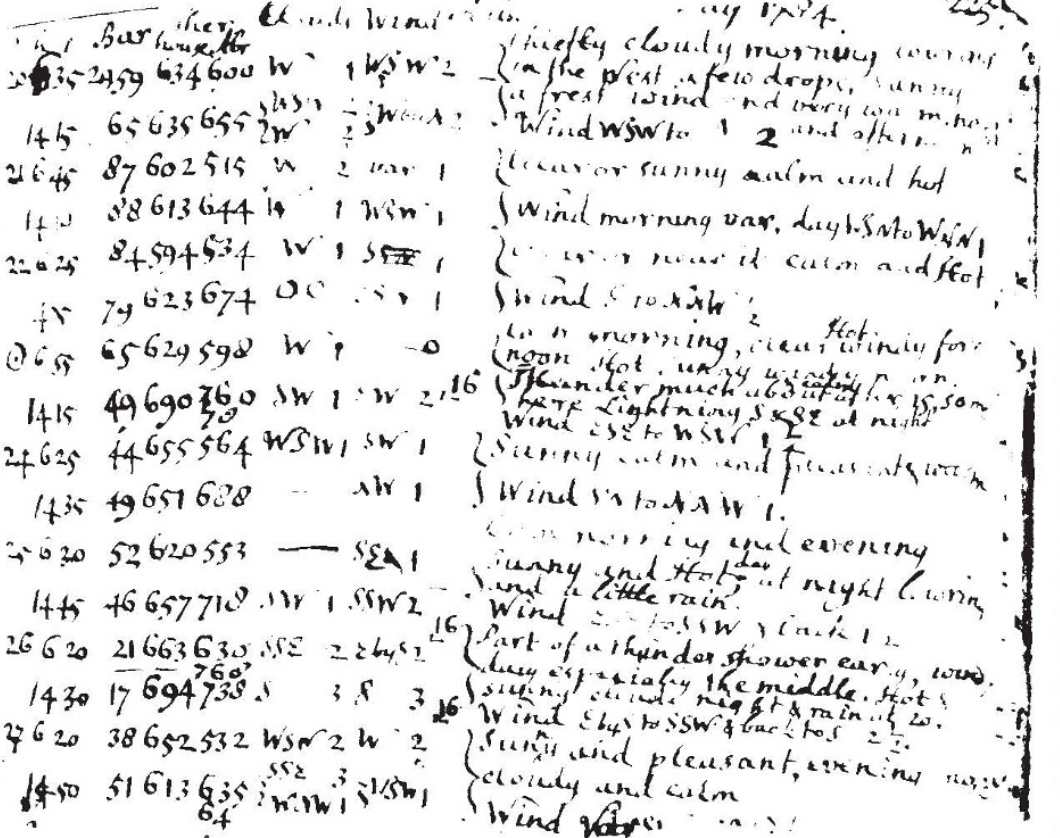

One leaves Kington's charming monograph with lasting respect for this trail-blazing climatologist - and with a wistful longing to know more of Barker the man. Whilst waiting for a fuller biography, I try to close the gap of centuries by picturing him in today's Rutland, now politically homogenized with "countries" he would have termed foreign. I see him at Lyndon Hall busily puttering away with his $\mathrm{PC}$, his ham radio, his collection of tropical fish. Of course, Lyndon Hall's acres would be festooned with automatic weather stations. On his bookshelves, beloved classics would be joined by Kafka and Kundera, and he University of East Anglia who studies eighteenth-century weather, has given us in this engaging little volume an ample selection of materials from the journals of Thomas Barker, together with brief but insightful sketches of the scientific and cultural worlds within which he lived, and the observational tools and methods he employed. Meteorology as a quantitative science was young. The barometer was less than a century old; the thermometer scarcely a half-century older. In 1723, when Barker was a toddler, the Royal Society began collecting weather journals bt struggle with enormous telephone bills and maintain lively correspondence equally with the Times and specialist journals. In the stables would stand his vintage Bugatti, next to his wellused Range Rover. This eighteenthcentury man of the country would have been thoroughly at home as a twentiethcentury man of science and the world.

John S. Perry is Staff Director of the Board on Atmospheric Sciences and Climate, National Academy of Sciences, 2101 Constitution Avenue NW, Washington, DC 20418, USA. 